\title{
Digital Business Value Creation with Robotic Process Automation (RPA) in Northern and Central Europe
}

\author{
DAMIAN KEDZIORA \\ Maria Curie-Sklodowska University in Lublin, Poland \\ damiankedziora@gmail.com \\ HANNA-MAIJA KIVIRANTA \\ University of Jyväskylä, Finland \\ hanna.kiviranta@gmail.com
}

In the rapidly changing global economy, robotics process automation (RPA) became one of the most important and fastest growing concepts. Digital value co-creation within service businesses and networks, sets value for end customer experience within more efficient operations, focusing on core business development with the use of modern technology. This pilot study approaches the topic from the practical perspective, presenting the results of empirical work conducted with experts working at the Intelligent Automation unit at one of the leading Nordic providers of financial and accounting services. It is examining the RPA transformation from the perspective of its impact on resourcing, operations and business value.

Key words: RPA, value, digital, business

https://doi.org/10.26493/1854-4231.13.161-174

\section{Introduction}

Digital customer value co-creation can be recognized as complex and multi-diverse aim for various service providers in their operations. Digitization of economy brings the customer into focus, and digital service delivery offers factors supporting value co-creation (Saarijärvi, Kannan, and Kuusela 2013; Vargo and Lusch 2014). Value co-creation has previously been used to denote collaboration between consumer product companies and their customers, and lately within в2в companies, as well as collaboration networks (Pralahad and Ramashwamy 2004). The broad opportunities created by digital tools allow companies to establish better communication channels among members of the sales, as well as between customers and vendors. This makes the exchange of information, both commercial (data sales), and administrative (data, documents, orders, price lists) faster and more efficient (Gohmann et al. 2005). 
More and more organizations, especially SMEs operating in the Nordic countries are currently considering or implementing automations and robotics at their operations. They seek for network of service providers of Automation-as-a-Service (Aaas), on-premise and various hybrid type of solutions. Digital business value co-creation is concentrated on forerunning company's market and brand identity's development with modern technology, digital solutions and business outsourcing that is focused on core business profitability with less risky in-housed resourcing, both in human workforce and ICT systems. Service providers and Іст business vendors aim for customer centric value co-creation and development for maximizing business growth opportunities, new technology development and value creation with their customers. In financial accounting markets there are also specific determinants for value co-creation that service providers and customers digitizing their accounting can benefit on. Those critical success factors are for example experience on the external financial accounting services, understanding customer's financial business logics, amount of manual data in various financial accounting processes, possibilities to harmonize various financial business processes, digital business development competences on finance, in-housed ERP with F\&A systems and IC T infrastructure, settled KPIs, business targets and mutual trust build between all parties.

Automation has been an essential component of business process management, originating from the manufacturing, financial and health care industries, based on the key focus on productivity, efficiency, and quality enhancement (Laycock and Hartmann 2005). Robotics process automation (RPA) in services industry is to be understood as the application of technology leading to automating business processes, when a company develops and configures software, or a 'software robot,' to capture and follow same steps in transaction processing, data manipulation, response triggering and even communicating with other digital systems, as a human worker (Boulton 2017). It has become a cutting-edge innovation (Willcocks, Lacity, and Craig 2015a), as the 'software robot' is imitating human employee by handling same structured tasks in a more efficient and faultless manner (Fung 2014). Starting from the exception handling that might include suspect entries, unrecognized accounts, data validation and synchronization across multiple systems, will be leading future tech processionals to leveraging RPA and AI to get as close to fully automated processes flow as possible (Castelluccio 2017).

Integrated in ERP systems or productivity tools via front-end so- 
lutions, the robot is not communicating with the system's Application Programming Interface (API), as has traditionally been required in the complex back-end solutions (Asatiani and Penttinen 2016). Robotics process automation is possible to be virtually integrated with any software used by a company, even the non-public one (Slaby 2012). Moreover, the lead time of its implementation is much shorter, as the robot is possible to be built and triggered to work in less than a month (Willcocks, Lacity, and Craig 2015b). The demise of work as an implication of the exponential and continuous progress in new digital and robotic ventures (Brynjolfsson and McAfee 2014), is believed to be one of the key concerns the future workers will need to face (Ford 2015). From the perspective of general human development, the robotic process automation (RPA) and artificial intelligence (AI) pose a risk to manual working, due to the automatizing of the work category that impact operations, processes and way of working (Nicholson, Sahay, and Heeks 2018).

Over the past few years there has been intensive technological and corporate changes in the global economy. The dynamic business conditions, affected by uncertainties related to the financial crisis of 2007-2008, forces many organizations to reconsider the value offered to the market and turn to innovative solutions also in finance and accounting industry. Therefore, many firms started to consider the technological advancements in operational digitalization and transformation linked to RPA within financial accounting. RPA can facilitate scaling up in a strategic way, in the same time helping companies to offer greater value to clients and customers (Vanmali 2017). Some authors point on the negative aspects of RPA, with key focus on the possibility of workforce reduction that evokes fear linked to the threat of greater inequality and higher unemployment (Spencer 2018). The bias and fear towards the technological changes resulting in the workload reductions has been present in economic and social debate for many decades (Hermann 2014).

The aim of the paper is to present the brief theoretical introduction, followed by the results of empirical interviews with RPA experts in Nordics, in the context of business value creation. The focus of this exploratory research is to discover insights and collect data that help to formulate new insights for future studies. The value co-creation with the strategic and operational focus of RPA transformations was identified from the practical perspective of implemented RPA cases. This approach to the topic from different levels and roles in the rapidly developing RPA environment is supposed to enhance current academic debate on the application of RPA in digital sales and busi- 
ness value creation. The paper shall address the following research questions:

1. What are the motivations and factors influencing service automation initiatives in Northern and Central Europe from the digital business value creation perspective?

2. What causes lead to sales value generation with actual impact on business, growth, profitability and full-time-equivalent (FTE) value?

\section{Methodology}

Case-oriented qualitative analysis attempts to understand a phenomenon from the standpoint of the participants (Braun and Clarke 2006). It reflects an interpretive research philosophy that is not geared to identifying causes but provides a different way to explain phenomena of digital business value co-creation with robotic process automation (RPA). In total, seven semi-structured interviews have been conducted with specific key experts of RPA implementation change. This type of work is characterized by having a fluid and flexible structure, although the predefined questions/topics to cover are present (Mason 2004). The semi structured interviews have been based on the following questions:

- Please describe latest RPA cases you have been involved in.

- Describe the industries on RPA case companies based on KPIS and business value creation.

- Which business processes have been automated and which ones need further optimizing and robotizing?

- What has been the best technology for each task and process to be automatized?

- Which automation process candidates have brought the highest benefit for the organization?

- Which tasks has been the best cost-benefit ratio with e.g. large amount of manual or repetitive tasks, big amount of data flows or time consuming human work with data at the moment?

- What kind of business value RPA have brought based on already automated cases?

- What has been the value of robotization for human work in the cases?

- How do you see the next steps in the digital value co-creation of changing work roles and routines with RPA at financial industry? 
TABLE 1 Roles and Times of Qualitative Case Observations and Semi Structured Interviews

\begin{tabular}{lll}
\hline Executive RPA business representative & $\begin{array}{l}\text { Case interviews } \\
\text { and observations }\end{array}$ & Location \\
\hline Head of product marketing - informant 1 & Jan 2018 & Norway \\
Head of intelligent automation - informant 2 & Feb 2018 & Finland \\
Development manager - informant 3 & March 2018 & Poland \\
Senior Consultant - informant 4 & March 2018 & Sweden \\
RPA developer - informant 5 & April 2018 & Poland \\
Sales executive - informant 6 & May 2018 & Finland \\
Junior Consultant - informant 7 & May 2018 & Finland \\
\hline
\end{tabular}

The themes of the questions were focused on research objective expressed in the former section of this paper that is the creation of value through implementing the RPA change at the finance and accounting operations. The interviews, followed by observations (meetings) were conducted in different stages of running projects in 4 locations, which took an average of two hours for each interviewee. The Informants were selected from persons with the most indepth knowledge of the company's activities, customers and value creation strategy. The Informants based in Finland were interviewed face-to-face, and the others by tele-conferences in English, Polish or Finnish. Table 1 presents the details of Informants' position, location and interviewing time.

The data got recorded and then transcribed for qualitative analysis with a total of 19 pages, performed later in line with the thematic analysis procedure (Braun and Clarke 2006), with the following steps:

1. Identifying of core topics and themes related to the objectives addressed above.

2. Assigning functional labels to various themes, in regards the relevant parts of the interview.

3. Reduction and collation of relevant data.

4. Sorting data in line with the below categories.

5. Impacts of RPA on FTE relations.

6. Cost effectiveness of RPA.

7. Delivery models offered to partners.

8. Flexibility of governance.

9. Impact of RPA on sales and marketing.

10. Digital value creation. 
11. Data verification, by synthesizing themes interpretations and consulting the results with the interviewed business experts for review.

The ethical concerns of confidentiality, privacy and anonymity have been addressed by allowing the Informants to identify other interviewed persons and protecting each participant's privacy by verification and analysis of data in smaller segments (Miles and $\mathrm{Hu}-$ berman, 1994, 293).

\section{Results and Discussion}

At the beginning of this section, the cases obtained from the informants taking part in this study are presented. Based on the interviews and observations on those cases, multiple pathway of RPA partnership with co-creative value outcome can be assumed, impacting business and workforce within various industries and types of RPA (table 2).

The data presents the impact on FTE savings, which can be seen as significant, as manual repetitive tasks have been automated. It does not mean that people have lost their jobs, but the transformation and change on the type of job has been obvious. Furthermore, no significant job losses related to RPA have been observed in studies (Willcocks, Lacity, and Craig 2015a). Nevertheless, the estimated cost savings related to the implementation of RPA vary among the available sources, from 0.1 to 0.5 of an offshore (FTE) (Prangnell and Wright 2015). Employees may perceive robots as their direct competitors if they are not properly engaged and made aware of the benefits of RPA transformation. This is often implemented with proper change management and training programmes within the RPA partnership.

We believe that the future accounting and financial services, based on the workers already released from the time-consuming, mundane and creativity-killing tasks should turn more to the role of accounting-consultancy. This is possible with RPA development. People working together with the businesses of our customers and focusing of enhancing their operations, in the same time we are strengthening their position and share on the market with the help of RPA solutions. [Informant 3]

In joint business efforts aiming for business value co-creation with licence providers, RPA consultants and business experts, continuously learning and enhancing the shared value will bring the best results for RPA business development onshore and nearshore, especially Aaas type. This elasticity and cost effectiveness make it 
TABLE 2 RPA Sales Value Creation with Impact on Business Value and Workforce (FTE) Robotization

\begin{tabular}{|c|c|c|c|c|}
\hline Industry & $\begin{array}{l}\text { Type } \\
\text { of RPA }\end{array}$ & $\begin{array}{l}\text { Business value out- } \\
\text { come }\end{array}$ & Business impact & FTE impact \\
\hline Public sector & $\begin{array}{l}\text { on } \\
\text { premise }\end{array}$ & $\begin{array}{l}\text { Architecture design, } \\
\text { production environ- } \\
\text { ment set-up, RPA li- } \\
\text { cences, trainings, on- } \\
\text { site support }\end{array}$ & $\begin{array}{l}9 \text { business pro- } \\
\text { cess tasks auto- } \\
\text { mated, } 6 \text { million } \\
\text { EUR of savings }\end{array}$ & $\begin{array}{l}80-120 \mathrm{FTE} \\
\text { robotized }\end{array}$ \\
\hline $\begin{array}{l}\text { Global } \\
\text { telecommu- } \\
\text { nications }\end{array}$ & Aaas & $\begin{array}{l}\text { Customer service and } \\
\text { invoice crediting, pro- } \\
\text { cessing invoice cred- } \\
\text { its in ERP and invoice } \\
\text { systems }\end{array}$ & $\begin{array}{l}2000 \text { ticket han- } \\
\text { dling/day, over } \\
75 \% \text { of business } \\
\text { processes auto- } \\
\text { mated }\end{array}$ & $\begin{array}{l}20 \text { FTE robo- } \\
\text { tized }\end{array}$ \\
\hline $\begin{array}{l}\text { Global engi- } \\
\text { neering }\end{array}$ & Aaas & $\begin{array}{l}\text { Financial reporting } \\
\text { with integrated BI and } \\
\text { for global business } \\
\text { controllers. }\end{array}$ & $\begin{array}{l}\text { Over } 50 \text { global } \\
\text { business units } \\
\text { and systems in- } \\
\text { tegrated with BI. }\end{array}$ & $\begin{array}{l}7 \text { FTE robo- } \\
\text { tized, over- } \\
\text { work and work } \\
\text { on Sundays } \\
\text { unnecessary }\end{array}$ \\
\hline Retail & Aaas & $\begin{array}{l}\text { Purchase to pay vali- } \\
\text { dating and amending } \\
\text { supplier data, entering } \\
\text { and approving sup- } \\
\text { plier master data }\end{array}$ & $\begin{array}{l}\text { Over } 300 \text { sup- } \\
\text { pliers managed } \\
\text { daily basis }\end{array}$ & $\begin{array}{l}\text { 1-2 FTE robo- } \\
\text { tized }\end{array}$ \\
\hline $\begin{array}{l}\text { Metal han- } \\
\text { dling tech- } \\
\text { nology }\end{array}$ & Aaas & $\begin{array}{l}\text { Treasury confirmation } \\
\text { process }\end{array}$ & $\begin{array}{l}50-80 \% \text { of pro- } \\
\text { cess automation } \\
\text { achieved }\end{array}$ & $\begin{array}{l}1 \text { FTE robo- } \\
\text { tized }\end{array}$ \\
\hline Logistics & Aaas & $\begin{array}{l}\text { Payroll process time } \\
\text { management, loca- } \\
\text { tion management, sick } \\
\text { notes handling. }\end{array}$ & $\begin{array}{l}\text { SAP integration } \\
\text { with all payroll } \\
\text { handling data }\end{array}$ & $\begin{array}{l}0.5 \text { FTE over } 10 \\
\text { FTE robotized }\end{array}$ \\
\hline
\end{tabular}

even more efficient than standard business process outsourcing and offshoring, applied already by many companies (Slaby 2012) which has lately been growing in Central Europe (Kedziora et al., 2017), along with the high focus on process optimization and improvement in nearshore locations (Kedziora, Kraslawski, and Kärri 2017).

Therefore, after the RPA pre-study conducted over a workshop with each customer, we are offering a comprehensive report with all the information and recommendations our customer needs for the decision making. It is often challenging to get the know all the data about the market and environment our customer is working for, especially when talking about onshore and nearshore sites. [Informant 2]

Creating value through business partners yields a higher value for 
customers than when the products and services are from individual sources (Sarker et al. 2012). Moreover, types of the RPA delivery models vary on industry bases, as within public sector it is more common to have on premise RPA solutions. In private business sector, it is more common to use RPA with Aaas licences and delivery models, where the company pays the provider right to use the software that is centrally hosted in a cloud. Aaas type of RPA model is not too tailored but can be flexibly designed to respond to the company needs for RPA. In addition, the sequencing of robots enables significant reduction in investment costs for the implementation compared to onpremise RPA business model.

Digitalizing financial accounting and other business process outsourcing services we are providing, by applying complex, end-to-end solutions, was always focused on increasing the offering portfolio, improving our customer experience and responding the needs to have efficient, state-of the art service support centres with scalable business model. [Informant 5]

Our business in both the with RPA as Aaas based service, onpremise centres and hybrid solutions with IA, allows us to develop best practices and methods in a responsible and conscious way. Usage and combined processing of various data sources brings us to the new dimensions of doing business. The value our robots will bring shall be visible in daily operations, that will be faster, easier, more precise and faultless. The easiness of implementing a robot either front or back end, relevance for creating actual business value and best customer experiences are on the top of all those criteria. [Informant 1]

On the top of the flexibility and versatility of RPA, there is modification easiness, as the relatively simple logic of process chart can be instructed to the robot (Asatiani and Penttinen 2016). The assessment of the processes and governance, degree of digitalization, and readiness for automation needs to be defined. Moreover, the customer should be performing the assessment of business and administration processes, in order to calculate the cost-benefit ratio per task.

Typical areas where software robots can be applied are finance and accounting, procurement, human resources, customer service operations and manual-intensive tasks linked with consolidation and migration of large data sets. [Informant 7]

Defining with task should be automated with technology is an- 
other challenging step in the RPA journey, as our experts need to recommend the solution that would added best customer value in all the conditions. Defining the strategy and road-map on the high-level is often motivated by the cost-savings potential and roll-out plan. Across the entire planning journey, we are proactively ready to refer to our experiences and business cases we have already implemented for reaching top value. [Informant 4]

Increasing importance of automated solutions to boost the sales processes through the development and value creation of innovative tools, enables the improvement of sales and marketing efficiency and effectiveness, so as the quality of long-term relationships with customers (Cardinali, Gregori, and Palanga 2014). The growing potential and significance of automations, as well as the success rates for its implementations have been linked to the adoption of tools by sales force, which is a critical factor for successful implementations that allows for productivity or efficiency increase, followed by the system boost (Puri 2011). While developing RPA, it is important to focus on strengthening actual business process value with delivered value for customers by ensuring the process integration, business case calculations and responsible execution in every step of automation journey.

The attractiveness of automation with the use of software robots is driven by the short implementation time from development to production. Traditional Iт projects would take months or even years, whereas a standard RPA implementation takes place in 23 months. Because of that, the RoI can be achieved far faster, even within 6 months. [Informant 6]

Customer is brought into focus within digitization and digital service processes offers functions for supporting the value co-creation (Vargo and Kusch 2014; Sarker et al. 2012; Pralahad and Ramashwamy 2004; Moeller 2008). According to service-dominant logic (Vargo and Lusch 2008; Vargo, Maglio, and Akaka 2008), both customer and service provider become resource integrators in value co-creation.

Today, every business and every person is exposed to the acquisition and processing of huge information flow daily. We are overwhelmed with words and numbers, as the multiple surrounding sources and fighting for our attention. Therefore, the computing of data and combining the duties that are time consuming, but not add much value has been on the top of operational excellence we aim for. The ease of use and best experi- 
ences can only be achieved by common innovative efforts within various partnerships. [Informant 3]

Future systems and platforms will certainly be driven by robots and automatized solutions in tight co-operation with IC т suppliers, RPA consultants and industry experts. Moving deeper and deeper in programming and computing should be allowing future workers to get released from those repetitive tasks and become more independent in their focus area of expertise. Efficient interaction and combination of human and robot needs to be harmonized under the big roof digital workforce with flexible joint efforts. [Informant 2]

\section{Conclusions}

The advancement of information and communication technology (IC T) and its rapid growth in modern digital economy have had substantial impact on sales management and business value creation (Honeycutt 2002). For any value co-creation, the service provider must consider certain risks and seek to enhance identified benefits, which are dynamic rather than static, making the development of digital services more complex (Rantala and Karjaluoto 2017). Markets are very diverse and competitive in Northern and Central Europe, when it comes to digitizing accounting processes, electronic invoices, digital payments, mobile banking and utilizing automation, scripts, macros and RPA for financial industry. In Finland, the market is highly developed, and companies are strongly proceeding with RPA in financial accounting, procurement, customer service (e.g. AI driven chat-bots) and many other business processes. In Germany, however, many companies are still using e.g. paper invoicing and manual payments even though service centre type of outsourcing and operations in financial management are proceeding. The interest towards RPA is increasing rapidly as with all Nordic markets now. Many companies have huge opportunities in digitization of the business processes but at the same time they also face challenges with change management of organization. Companies need to gain new competences and understanding on how future work is evolving and what kind of competences their personnel also need to develop to be able to be competitive in markets. In the same time, the debate is highlighting the need for complex understanding of political and economic dimensions of technological advancements and possibilities for utilising new technologies for the good of the whole society. There is not much convincing evidence that the large-scale 
unemployment related to new technologies is happening now or will happen in the immediate future, as the real issue is the current unequal distribution of work, time and money (Wajcman 2017). In the same time, the hope in technology that helps extending employee's freedom and human well-being both within and without work has been noticed (Sayers 2005). Some of the studies are going even beyond that, embracing automation as a route to the 'post-work' utopia (Mason 2015), calling for a complex programme of 'full automation' and looking forward to a time when manual, mundane work is released or even abolished (Srnicek and Williams 2015).

As seen in the results of this study, the deterministic outcomes brought by RPA as financial accounting digitization to customer value co-creation, provided by service provider within aaas service or onpremise is crucial in terms of speed, costs, efficiency, savings, productivity and error reduction. This is also linked to the releasing of employees from the mundane tasks to more co-creative, valueadding ones. Moving from the manufacturing industry to services in financial accounting, RPA explores the back-office business areas with front and back end solutions, transforming the way highvolume, repeatable work will in the future the done by faultless and efficient robots (Geyr 2015). There are wide range of on-premise RPA solutions, RPA as Aaas and hybrid solutions available in markets. Especially Aaas enables cross-industrial collaboration and technological evolution with value co-creation for companies in the future. This is possible when firms among the enterprise systems and financial services industries partner to create added value for customers by connecting and integrating services (Teracino 2017). The results of this work prove the co-creating of digital value and change management processes important, also for personnel competence development, extensive vendor networks, teamwork, trust, innovations and process harmonizing, before actual RPA implementations. From the practical perspective, the implications for managerial community are to carefully assess the automation potential, focusing on the material that is free from human judgement, free from analogue text, or digitalized to the extent that RPA software manages to work on, as well as with well-defined business rules and high-level requirements.

The study was limited by the number and time of investigation but was strictly focused on the practical perspective of the aspects taken into consideration by the top RPA business practitioners. Therefore, it is recommended to continue the research on the topic by comparative work in respect other locations and strategies, aligned with the growing importance in the value being created by RPA in modern 
digital economy. As actual sales co-creation value success RPA development leads to a situation where automating monotonous tasks release focus on more complex work tasks, while it requires personnel competence development and more complex tasks, such as improved customer service, resulting in higher business growth opportunities, profitability and society well fare.

\section{References}

Asatiani, A., and E. Penttinen. 2016. 'Turning Robotic Process Automation into Commercial Success: Case OpusCapita.' Journal of Information Technology Teaching Cases 6 (2): 67-74.

Braun, V., and V. Clarke. 2006. 'Using Thematic Analysis in Psychology.' Qualitative Research in Psychology 3 (2): 77-101.

Brynjolfsson, E., and A. McAfee. 2014. The Second Machine Age: Work, Progress, and Prosperity in a Time of Brilliant Technologies. New York: Norton.

Boulton, C. 2017. What is RPA? A Revolution in Business Process Automation. Hong Kong: Computerworld.

Cardinali, S., G. Gregori, and P. Palanga. 2014. 'SFA Adoption: Empirical Evidences from a Case Study.' International Journal of Business and Social Research 4 (6): 123-36.

Castelluccio, M. 2017. 'Artificial Intelligence in Business.' Technology Workbook 98 (10): 55-57.

Ford, M. 2015. The Rise of the Robots: Technology and the Threat of Mass Unemployment. London: Oneworld.

Fung, H. P. 2014. 'Criteria, Use Cases and Effects of Information Technology Process Automation (IтPA).' Advances in Robotic and Automation 3 (3): 1-11.

Von Geyr, J. 2015. 'Adopting Robotic Process Automation Requires Initiative from Workforce and Leadership Alike.' Manufacuring.net, 15 October.

Gohmann, S. F., J. Guan, R. M. Barker, and D. J. Faulds. 2005. 'Perceptions of Sales Force Automation: Differences between Sales Force and Management.' Industrial Marketing Management 34 (4): 337-43.

Hermann, C. 2014. Capitalism and the Political Economy of Work Time. Abingdon: Routledge.

Honeycutt, E. D. 2002. 'Sales Management in the New Millennium: An Introduction.' Industrial Marketing Management 31 (7): 555-558.

Kedziora, D., T. Karri, A. Kraslawski, and M. Halasa. 2017, 'Nearshore Service Transfers in the Ev: Legal and Economic Issues.' Economics and Sociology 10 (1): 290-309.

Kedziora, D., A. Kraslawski, and T. Kärri. 2017. 'Reengineering of Offshored гт Helpdesk Operational Model for Transitional Optimization.' International Journal of Management and Decision Making 16 (4): $375-406$.

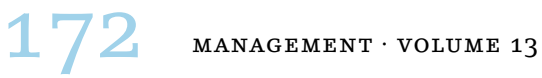


Laycock, J. D., and T. Hartmann. 2005. Automation. In Integrated Strategies for Drug Discovery Using Mass Spectrometry, edited by M. S. Lee, 511-542. New York: Wiley.

Mason, P. 2015. Postcapitalism: A Guide to Our Future. London: Allen Lane.

Mason, J. 2004. 'Semistructured Interview.' In The Sage Encyclopedia of Social Science Research Methods, edited by M. S. Lewis-Beck, A. Bryman, and T. F. Liao, 1020-1029. Thousand Oaks, cA: Sage.

Miles, M. B., and A. M. Huberman. 1994. Qualitative Data Analysis. Thousand Oaks, cA: Sage.

Moeller, S. 2008. 'Customer Integration: A Key to an Implementation Perspective of Service Provision.' Journal of Service Research 11 (2): 197-210.

Nicholson, B., S. Sahay, and R. Heeks. 2018. 'Global Sourcing and Development: New Drivers, Models, and Impacts.' Information Systems Journal 28 (3): 532-37.

Prahalad, C. K., and V. Ramaswamy. 2004. 'Co-Creating Unique Value with Customers.' Strategy \& Leadership 32 (3): 4-9.

Prangnell, N., and D. Wright. 2015. 'The Robots Are Coming.' http:// www2.deloitte.com/content/dam/Deloitte/uk/Documents/finance/ deloitte-uk-finance-robots-are-coming.pdf

Puri, S. 2011. 'Value Drivers for Technology Enabled Sales Force Automation.' International Journal of Electronic Customer Relationship Management 5 (3): 259-71.

Rantala, K., and H. Karjaluoto. 2017. 'Combining Digitization with Healthcare Service Processes: Value Co-Creation Opportunities through Standard Work.' In Proceedings of the zoth Bled eConference: Digital Transformation; From Connecting Things to Transforming Our Lives, edited by A. Pucihar, M. K. Borštnar, C. Kittl, P. Ravesteijn, R. Clarke, and R. Bons, 471-482. Maribor: University of Maribor Press.

Saarijärvi, H., P. K. Kannan, and H. Kuusela. 2013. 'Value Co-Creation: Theoretical Approaches and Practical Implications.' European Business Review 25 (1): 6-19.

Sarker, S., S. Sarker, A. Sahaym, and N. Bjorn-Andersen. 2012. 'Exploring Value Cocreation in Relationships between an ERP Vendor and its Partners: A Revelatory Case Study.' MIs Quarterly 36 (1): 317-38.

Sayers, S. 2005. 'Why Work? Marxism and Human Nature.' Science and Society 69 (4): 606-16.

Slaby, J. 2012. 'Robotic Automation Emerges As a Threat to Traditional Low-Cost Outsourcing.' https://www.hfsresearch.com/report/robotic -automation-emerges-threat-traditional-low-costoutsourcing

Spencer, D. A. 2018. 'Fear and Hope in an Age of Mass Automation: Debating the Future of Work.' New Technology, Work and Employment 33 (1): 1-12. 
Srnicek, N., and A. Williams 2015. Inventing the Future: Postcapitalism and a World without Work. London: Verso.

Teracino, E. A. 2017. 'Value Co-Creation in the Cloud: Understanding Software-as-a-Service-Driven Convergence of the Enterprise Systems and Financial Services Industries.' Doctoral dissertation, University of Groningen, Groningen.

Wajcman, J. 2017. 'Automation: Is It Really Different This Time?' The British Journal of Sociology 68 (1): 19-127.

Willcocks, L. P., and M. Lacity, and A. Craig. 2015a. 'Robotic Process Automation at Xchanging.' The Outsourcing Unit Working Research Paper Series 15/03, The London School of Economics and Political Science, London.

- 2015b. 'The Iт Function and Robotic Process Automation.' The Outsourcing Unit Working Paper Series 15/05, The London School of Economics and Political Science, London.

Vanmali, K. 2017. 'Robotic Software Will Help cfos To Play A More Strategic Role.' Accountancy South Africa, 1 february. https://www .accountancysa.org.za/upfront-robotic-software/

Vargo, S. L., and R. F. Lusch. 2008. 'Service-Dominant Logic: Continuing the Evolution.' Journal of the Academy of Marketing Science 36 (1): 110.

2014. 'Institutions and Axioms: An Extension and Update of Service Dominant Logic.' Journal of the Academy of Marketing Science 44 (1): $5^{-23}$.

Vargo, S. L., P. P Maglio, and M. A. Akaka. 2008b. 'On Value and Value Co-Creation: A Service Systems and Service Logic Perspective.' European Management Journal 26 (3): 145-152.

This paper is published under the terms of the AttributionNonCommercial-NoDerivatives 4.0 International (CC BY-NC-ND 4.0) License (http://creativecommons.org/licenses/by-nc-nd/4.o/). 